\title{
Quando só a imprensa leva a culpa (mesmo sem tê-la)
}

EUGENAIO BUCCI

\section{De como a excelência jornalística desembocou na censura judicial que amordaçou o diário $O$ Estado de S. Paulo}

“P OBRES JORNALISTAS!", exclama o francês Yves Mamou (1992, p.201), na conclusão de seu livro $A$ culpa é da imprensa. "Quando a calma reina na sociedade, são acusados das piores conivências com suas fontes. Quando uma crise explode, transforma-se em perseguidores de seus informantes...".

Antes de mais considerações, façamos um pequeno reparo. Jornalistas não são "pobres" - aqui significando "vítimas desprotegidas". Sem fazer piada de gosto duvidoso, é preciso reconhecer que jornalistas podem ser "pobres" em função de seus salários, economicamente falando, mas não são "pobres" nesse sentido que Yves Mamou dá à palavra, não são injustiçados, incompreendidos, não são coitadinhos. Como regra, sabem se defender muito bem. As redações, os jornais, a instituição da imprensa tem sido capaz de se afirmar e de repelir os ataques que recebe. Não obstante, é verdade indiscutível que, assim como nos romances policiais se diz que o culpado acaba sendo o mordomo, a imprensa sai das crises políticas com a pecha de ter contribuído para agravar o sofrimento social. Nisso, temos uma das raras unanimidades suprapartidárias no Brasil e no mundo: quando se trata de pôr a culpa na imprensa, quase todos estão de acordo, ainda que com motivos antípodas.

O poder não gosta da imprensa - apenas é forçado a conviver com ela. Cinicamente, se necessário. Captando com genialidade e crueza esse espírito um tanto maligno do tempo, Max Weber anota em A política como vocação o modo como os poderosos o exprimem. Diz Weber (2006, p.84) a respeito da condição do profissional do jornalismo:

É de mencionar, por exemplo, a circunstância de freqüentar os salões dos poderosos da Terra, aparentemente em pé de igualdade, vendo-se, em geral e mesmo com freqüência, adulado, porque temido, tendo, ao mesmo tempo, consciência perfeita de que, abandonada a sala, o anfitrião sentir-se-á, talvez, obrigado a se justificar diante dos demais convidados por haver feito comparecer esses "lixeiros da imprensa".

O termo "lixeiro", bem a propósito, lembra a palavra em inglês muckraker ("aquele que divulga a sujeira", numa tradução livre). Era com essa palavra, muckraker, que o presidente americano Theodore Roosevelt (1858-1919) se 
referia por vezes a repórteres e seus patrões, como Joseph Pulitzer (1847-1911), a quem tentou processar em função das revelações que o jornal World (de Pulitzer) fizera sobre a construção do Canal do Panamá, ainda nos primeiros anos de seu governo (que se estendeu de 1901 a 1909) (Pulitzer, 2006, p.7).

A estranheza entre a lógica do poder e a missão dos que publicam notícias tem a mesma idade que a democracia moderna. Vem do século XVIII. É estrutural e estruturante. Tanto que, mesmo aqueles políticos originados do ramo das comunicações, empresários ou jornalistas de projeção, adotam, uma vez no poder, um olhar tenso em relação aos meios de comunicação. Às vezes, agridem verbalmente os velhos colegas de ofício. Outras vezes, chegam a processá-los. O caso mais, por assim dizer, caricato, mas profusamente expressivo, é o do italiano Silvio Berlusconi, magnata da TV italiana e atualmente primeiro-ministro de seu país, que desde o início de 2009 vem se dedicando ao esporte de jogar nos veículos informativos a responsabilidade pelas vergonhas que marcam seu governo, como a de ter sido fotografado, em sua propriedade, ladeado por prostitutas.

Em reportagem publicada no jornal $O$ Estado de S. Paulo de 5 de setembro de 2009 ("Defesa de Berlusconi ultrapassa limite ético"), o correspondente Gilles Lapouge informou que

Berlusconi lançou um ataque contra aqueles que o acusam de relacionar-se com jovens e de receber prostitutas e garotas de programa em sua paradisíaca propriedade na Sardenha. Por isso, a mulher de Berlusconi, Veronica Lario, pediu o divórcio. Esse contra-ataque vem causando barulho e lançando muita lama. Berlusconi processou o jornal italiano La Reppublica por difamação. [...] O jornal tem publicado diariamente perguntas do tipo: "O senhor sabia que dezenas de mulheres que recebeu em sua casa eram prostitutas?".

Os jornais estrangeiros também não foram poupados. Uma ação judicial foi aberta contra o semanário francês Le Nouvel Observateur, que fez um relato das festas faraônicas e eróticas do Cavalieri. Outro jornal foi o El Pais, que publicou fotos de mulheres nuas na mansão dele.

No Brasil recente, há um fenômeno bem parecido. O presidente do Senado Federal, José Sarney - cuja família é proprietária da TV Mirante, afiliada da Globo no Estado do Maranhão, além de outros veículos jornalísticos -, também vem falando com ênfase cada vez mais eloquente sobre conspirações e perseguições movidas pelos jornais contra ele, contra o Senado, contra seus familiares, seus amigos etc. No dia 15 de setembro de 2009, essa escalada de ataques atingiu o ponto mais estridente, quando o senador declarou que "a mídia passou a ser uma inimiga do Congresso, uma inimiga das instituições representativas". A onda de ataques do presidente do Senado, a propósito, é o que dá mote ao presente artigo - e falaremos mais adiante sobre os significados aparentes e ocultos dessa declaração. Mas não trataremos aqui apenas dos ataques retóricos; para melhor refletir sobre a saga do bom jornalismo que acabou sendo premiado com censura, é preciso levar em conta, além dos discursos, as medidas judiciais que produziram a censura, ou seja, a ação movida pelo filho do senador, o empresá- 
rio Fernando Sarney, que conseguiu, graças a um desembargador do Tribunal de Justiça do Distrito Federal, impedir O Estado de S. Paulo de publicar notícias sobre sua pessoa.

\section{Algumas reminiscências curiosas}

Contudo, antes de mergulharmos no tema específico do Estadão e do cerco que sobre ele se abateu, convém recapitular, ainda que rapidamente, o modo como a síndrome de pôr a culpa nos jornais se espraia como um denominador comum pelas mais disparatadas doutrinas e correntes partidárias e ideológicas. Há um exemplo antigo, já quase esquecido, que é bem ilustrativo. Mostra que o discurso do poder contra os jornais, qualquer que seja o poder, praticamente desconhece variações. Mudam apenas seus enunciadores, que vão da esquerda à direita, de um lado para o outro. No mais, até mesmo as palavras que eles usam são as mesmas.

O episódio que será lembrado aqui aconteceu em agosto de 1977, nos estertores da fase mais selvagem da ditadura militar. No dia 8 daquele mês, Goffredo Telles Júnior, professor do Largo São Francisco, leu, em ato público, nas Arcadas, no pátio da própria faculdade, em São Paulo, a sua célebre "Carta aos Brasileiros". Assinado por vários juristas além do próprio Goffredo, o documento caracterizava o regime brasileiro como ditatorial, sem meias palavras, e pedia o "Estado de Direito Já!". No dia seguinte, a "Carta" ganhou espaço em todos os jornais e, no dia 10, as repercussões alcançaram o plenário da Câmara dos Deputados, em Brasília. O deputado Freitas Nobre, então líder do MDB, o partido de oposição, saudou o gesto dos professores da São Francisco. Foi aplaudido. Em seguida, Cantídio Sampaio, líder da Arena, o partido da ditadura, solicitou um aparte, que the foi concedido pelo presidente da casa, Marco Maciel. Disse Cantídio:

Sinceramente, não encontramos aqui um pensamento inédito. Os jornais, que são o grande veículo desta campanha articulada que essas organizações se apostam têm acolhido trabalhos de juristas como Seabra Fagundes, Aliomar Baleeiro e outros tantos, muito mais profundos, mais significativos e muito mais abrangentes, mas todos eles, senhor presidente, pecando por pretender abarcar a complexidade do problema político brasileiro apenas pelo seu aspecto jurídico. ${ }^{1}$

O líder da Arena enxergava no noticiário uma "campanha articulada" contra o governo, campanha da qual "o grande veículo" seriam "os jornais". Ele falava como se seu governo fosse injustiçado, perseguido, mas, no fundo, o seu discurso era o discurso do poder. Na visão do poder, as responsáveis pelo malestar e pela insatisfação da sociedade só podiam ser as redações. Quem mais? ${ }^{2}$

Depois da ditadura, outra manifestação clamorosa dessa mesma tendência, tão própria do poder, surgiu no ocaso do governo de Fernando Collor. Ao longo do ano de 1992, seus defensores insistiram em atribuir às reportagens sobre a corrupção no governo a causa da grande mobilização que resultou no impeachment do presidente. Desde então, pode-se dizer, o método de desqualificar matérias jornalísticas com o argumento de que elas não são "inéditas", 
como pretendeu Cantídio Sampaio, virou lugar-comum. Mais recentemente, fala-se em "fatos requentados", que "não trazem novidade", para desqualificar os jornais do mesmo modo. No mais, os bordões são recorrentes: "campanha articulada", "a imprensa é um partido de oposição" etc. Vale repetir: a despeito da mudança das cores ideológicas de quem governa, o discurso anti-imprensa não varia, é monocórdio.

\section{Os escândalos propriamente ditos}

Voltemos então ao ano de 2009. Novamente, os embates do poder contra as redações ganham a cena. Agora, o polo incomodado está no Poder Legislativo. Mais precisamente, está no Senado Federal. Em poucos meses, diversos jornais, emissoras de rádio e telejornais veicularam manchetes sobre centenas de atos administrativos praticados pela direção do Senado - atos que concediam aumentos, contratavam funcionários e determinavam outras medidas - que, contrariando todos os princípios da administração pública, não eram publicados no Diário Oficial. Descobertos, esses atos logo ficaram conhecidos como "atos secretos", pois era exatamente o que eram, secretos. Por definição, eram ilegais. Vários desses atos empregavam ou beneficiavam parentes de senadores. O presidente do Senado, José Sarney (PMDB-AP), cujos parentes e afilhados ganharam proeminência com a revelação dos atos secretos, passou a bater duro contra os repórteres. Desde que a crise começou. Outra vez, um político veio a público para pôr a culpa na imprensa.

Ainda antes da descoberta dos atos secretos, quando o escândalo ainda não era tão escandaloso assim, quando as principais denúncias cuidavam apenas de uma residência suntuosa à beira do lago, cujo proprietário, então diretor-geral do Senado, Agaciel Maia, julgara por bem não declará-la como sua à Receita Federal, José Sarney já reclamou dos noticiários.

Nós estamos sendo o que popularmente se chama de boi de piranha. Enquanto tudo passa, nós ficamos aqui na frente. $\mathrm{E}$ os grandes problemas não estão surgindo. Está $[s i c]$ se discutindo pequenas coisas. ${ }^{3}$

O que ele quis dizer exatamente? Bem, ele quis dizer que, se alguém estava errado nessa história, esse alguém era quem editava os noticiários. $\mathrm{Na}$ opinião dele, em vez de se ocupar do que interessa de verdade, os jornais ficam por aí perdendo tempo, girando em torno de "pequenas coisas".

Não que Sarney tenha ficado parado, não que ele tenha ignorado solenemente as notícias sobre as tais "pequenas coisas". Na dúvida, ele também se ocupava de algumas das "pequenas coisas". Afastara Agaciel Maia da direção-geral da Casa logo na primeira semana de março. Sumariamente, também comentou outro questionamento pendente por aqueles dias, sobre o uso de agentes da segurança do Senado para vigiar sua casa particular em São Luís, capital do Maranhão, mas esse caso caiu no vazio. Dias depois, entrariam na pauta denúncias mais graves, como o pagamento de horas extras para funcionários que não as cumpriam e a existência de quase duzentas diretorias sem finalidades precisas. $\mathrm{O}$ 
quadro se complicava aceleradamente, até que, no dia 6 de abril, uma segundafeira, o senador Cristovam Buarque (PDT-DF) lançou a ideia de se submeter a plebiscito a manutenção ou a extinção do Congresso Nacional - proposta que também seria deixada de lado. ${ }^{4}$ Parecia que nada poderia ficar pior do que já estava. Mas ficou.

Não houve plebiscito nenhum, como se sabe, mas, a despeito de tantos indicadores de desmandos, o discurso lamuriento de que o pobre Senado tinha virado "o que popularmente se chama de boi de piranha" ganhou força. Semana a semana, esse espírito preventivo contra os meios de comunicação só fez crescer entre os parlamentares. No dia 8 de abril de 2009, uma quarta-feira, vários deputados de destaque engrossaram o coro dos descontentes. O Estadão de quinta-feira, 9 de abril de 2009, registrou o fato na página A8: "Câmara culpa mídia por imagem negativa". Ninguém menos que o presidente da Câmara, Michel Temer, afirmara em plenário:

Menos as notícias, talvez mais as manchetes e as fotos visam colocar a Câmara dos Deputados em confronto com a opinião pública. Veja que a cultura política vai sendo construída de uma maneira que, se nós não repudiarmos um pouco, não tivermos uma ação muito concreta em relação a isso, não estaremos fazendo um benefício à democracia.

Outros deputados o secundaram, à esquerda e à direita. Mais uma vez, ficou evidente que o cacoete de culpar o noticiário é uma unanimidade suprapartidária. O líder do PT, Cândido Vaccarezza, logo apresentou seu diagnóstico:

Os editores estabelecem um tema e os jornalistas são obrigados a enquadrar a realidade naquele tema. Não importa o que o deputado fale. Isso pega a todos. Não contribui para a democracia.

Na sequência, falou também Ronaldo Caiado, do DEM: "É inaceitável. Não é possível essa campanha difamatória que aumenta a cada dia". ${ }^{5}$

Qual tinha sido a razão para investidas tão peremptórias? Talvez o fato de que, daqueles dias, ter circulado a informação de que a Câmara destinaria 80 milhões de reais para reformar apartamentos funcionais dos parlamentares. Alegaram que a notícia não seria bem aquela, que haveria má vontade dos repórteres, movidos por um propósito inequívoco de corroer a imagem da casa. Como ficou bem claro naquele dia 8 de abril, os representantes do povo, do PT ao DEM, passando pelo PMDB, discordam entre si sobre as mais diversas matérias, mas, nisto, estão de acordo: a culpada é a imprensa.

Mas a razão para os descontentamentos talvez tivesse parte, também, com outras notícias que ganhavam visibilidade naquela semana. Na quarta-feira, 8 de abril de 2009, no mesmo dia em que os deputados emitiram suas críticas, uma notícia exclusiva de $O$ Estado de S. Paulo perturbou outra vez a paz no Senado Federal: o senador Tião Viana (PT-AC) emprestara o celular de seu uso pessoal (um aparelho do Senado Federal) para a filha, que viajara em férias para o México, e a conta atingira a casa dos 14,7 mil reais. O furo, numa reportagem de Rui 
Nogueira e João Bosco Rabello, fez a tensão subir. Mais uma vez, a pontaria dos repórteres irritou os políticos.

\section{A crise se agrava}

Naturalmente, os mais diversos órgãos noticiosos, como a Folha de S.Paulo, $O$ Globo, os telejornais das principais emissoras e as revistas semanais também cobriram com afinco os desmandos do Senado Federal. O Estadão, porém, destacou-se com liderança reconhecida por todos os demais. No final, apenas ele ganharia o prêmio maior: uma censura judicial que, até o dia em que este artigo é fechado, se estendia por 60 dias. Algo de inacreditável numa democracia. Por isso, também, o foco do presente texto se concentra sobre a trajetória do Estadão. Esse caso deve ser mais estudado do que foi, mais debatido, mais conhecido - exatamente para evitar que os ataques por ele sofridos não prosperem mais do que já prosperaram.

A partir do mês de junho de 2009, as revelações de mais e mais capítulos do escândalo. Façamos, aqui, uma breve retomada das notícias de maior impacto, conforme retrospectivas publicadas pelo próprio diário paulistano. ${ }^{6}$

10 de junho:

Em mais um furo jornalístico (reportagem de Rosa Costa e Leandro Colon), o Estado revela a existência de mais de 300 atos secretos para criar cargos e nomear parentes de políticos para o Senado. Conversas telefônicas comprovaram o envolvimento do presidente da Casa, José Sarney, com os atos secretos e a prática de nepotismo.

18 de junho:

A comissão de sindicância que analisa os atos secretos do Senado divulgou que detectou cerca de 650 decisões mantidas sob sigilo nos últimos anos.

20 de junho:

Reportagem do Estado, assinada por Rosa Costa e Rodrigo Rangel, revela que o mordomo de Roseana Sarney, Amaury de Jesus Machado, conhecido pela alcunha de "Secreta", recebe 12 mil reais por mês do Senado.

\section{3 de junho:}

Nova reportagem de Rosa Costa e Rodrigo Rangel noticia que dois funcionários - Raimundo Nonato Quintiliano Pereira Filho e Fernando Nelmásio Silva Belforte - que trabalham na Fundação José Sarney, em São Luís (MA), são assessores do Senado.

25 de junho:

Em novo furo jornalístico, em reportagem de Rodrigo Rangel e Rosa Cos- 
ta, mostra que o esquema do crédito consignado no Senado inclui entre seus operadores José Adriano Cordeiro Sarney, filho do deputado Zequinha Sarney, filho mais velho de José Sarney.

16 de julho:

O Estadão noticia, em matéria de Rodrigo Rangel, que a Operação Boi Barrica esbarrou em provas contra o grupo do empresário Fernando Sarney, filho de José Sarney, que é indiciado. A Polícia Federal divulgou que o grupo usava o poder do sobrenome Sarney para ter acesso a ministérios e estatais. Fernando Sarney foi interrogado na PF do Maranhão.

22 e 23 de julho:

Estado publica diálogos gravados entre 30 de março e 2 de abril de 2008, que mostram a articulação para a nomeação de Henrique Dias Bernardes, namorado de Maria Beatriz Brandão Cavalcanti, filha de Fernando Sarney, para cargo no Senado.

Atenção para as reportagens dos dias 22 e 23 de julho. Elas são cruciais para o entendimento do caso. Fernando Sarney teve suas conversas telefônicas registradas em gravações com autorização judicial em procedimento de investigação criminal protegida sob o manto de segredo de justiça. Foi com base nesse segredo, e também com base na alegação de que sua intimidade familiar resultaria exposta, que ele solicitou à Justiça que o jornal O Estado de S. Panlo fosse impedido de publicar dados sobre ele. Como veremos a seguir, na continuação da retrospectiva, ele seria bem-sucedido em sua pretensão:

31 de julho (o dia em que a censura entre em cena):

O desembargador Dácio Vieira, do Tribunal de Justiça do Distrito Federal (TJ-DF), informa o Estado da proibição de publicar informações sobre a Operação Boi Barrica (PF). Começa a censura judicial.

1 o de agosto:

O jornal revela que o desembargador Dácio Vieira, ex-consultor do Senado, é do convívio dos Sarney e do ex-diretor do Senado Agaciel Maia. A Associação Nacional de Jornais (ANJ), outras entidades, senadores e o ex-ministro do STF Carlos Velloso criticam decisão.

5 de agosto:

O advogado Manuel Alceu Affonso Ferreira pede que o desembargador que censurou o Estado imediatamente se declare suspeito para tomar decisões no processo. A exceção de suspeição é protocolada no próprio Tribunal de Justiça do DF. O requerimento sustenta que há laços entre Dácio Vieira, Fernando Sarney e Agaciel Maia. 
10 de agosto:

Associação Mundial de Jornais (WAN) e Fórum Mundial de Editores (WEF), que representam 18 mil publicações, 15 mil sites e mais de 3 mil empresas em mais de 120 países enviam carta a Lula e ao presidente do STF, Gilmar Mendes, criticando liminar da censura.

12 de agosto:

Estado entra com mandado de segurança. O recurso tem o objetivo de garantir o reconhecimento de direito líquido e certo, incontestável, que está sendo violado ou ameaçado por ato ilegal ou inconstitucional de uma autoridade.

13 de agosto:

O desembargador Waldir Leôncio Cordeiro, da $2^{\underline{a}}$ Câmara Cível do TJ, mantém censura ao jornal, ao não acolher pedido de liminar no mandado de segurança. Cordeiro deixa para deliberar após receber dados de Vieira e da Procuradoria.

14 de agosto:

O desembargador Vieira conclui que é competente para julgar o processo. Caso segue para Conselho Especial do TJ. Ministro Marco Aurélio Mello, do STF, critica censura ao Estado. Entidades continuam a repudiar a censura

17 de agosto:

Mendes cobra decisão rápida sobre o caso. O advogado Manuel Alceu ingressa no TJ-DF com um novo recurso. Por meio de embargos de declaração, ele requer ao desembargador Lopes Júnior que esclareça pontos de sua decisão.

\section{1 de agosto:}

Estado ingressa com nova exceção de suspeição do desembargador Dácio Vieira. A base do recurso é extraída da própria decisão de Vieira, quando ele ignorou um primeiro pedido para que se declarasse suspeito no caso.

15 de setembro:

O TJ-DF declara Vieira suspeito para decidir sobre o pedido de censura. A decisão afasta o desembargador do caso. No mesmo dia foi indicado o novo relator, Lecir Manoel da Luz. Mas a censura é mantida.

30 de setembro:

O jornal continua sob censura. 
A decisão do desembargador Dácio Vieira - que, como observado anteriormente, atendeu ao pedido do empresário Fernando Sarney, que queria impedir a publicação de reportagens referentes às investigações que vem sofrendo no jornal O Estado de S. Paulo - tem um espectro, como se verá, bastante amplo. Vale transcrever, aqui, o trecho final da peça, com data do dia 30 de julho de 2009. Trata-se de uma decisão liminar, ou seja, ainda será reavaliada pelo Tribunal, mas, mesmo depois do afastamento de Vieira, declarado suspeito, ela continua efetiva, não foi revogada (até a data de fechamento deste artigo, 30 de setembro de 2009). E tem força para praticamente "blindar" o empresário contra qualquer reportagem. Vejamos:

Nesse quadro, em juízo de summaria cognitio, a refletir, prima facie, a relevância dos fundamentos expendidos no presente recurso, evidenciando-se a possibilidade de ocorrência de lesão grave de difícil reparação, cumpre conceder a medida liminarmente visada, consistente em obrigação de não fazer, até o pronunciamento definitivo da Colenda Turma, para determinar ao agravado, em antecipação da tutela recursal, que se abstenha quanto à utilização - de qualquer forma, direta ou indireta - ou publicação dos dados relativos ao agravante, eis que obtidos em sede de investigação criminal sob sigilo judicial.

Note-se que, nos termos da decisão tal como o desembargador a redigiu, qualquer dado relativo ao agravante (Fernando Sarney) não poderá ser publicado. O texto reproduzido não fala em conversas telefônicas apenas, mas em "publicação dos dados relativos ao agravante". Isso bloqueou, no jornal, a veiculação de reportagens que já tinham sido apuradas no período imediatamente anterior à decisão do desembargador.

Assim foi que, pelo reconhecido padrão de excelência jornalística, conseguindo uma sequência de notícias exclusivas e de grande impacto sobre o escândalo do Senado, o Estadão se viu premiado com a censura judicial. Como disse o professor de Ética Jornalística Carlos Alberto Di Franco, em debate na redação do jornal, no dia 6 de agosto, que foi transmitido ao vivo pela TV Estadão na internet: "Estamos assistindo a uma onda de podridão no Senado e nenhum senador foi punido. O único punido foi um jornal, que disse a verdade. Isso é impunidade".?

Como que para não desmentir o desalento do professor Di Franco, a Comissão de Ética e Decoro Parlamentar do Senado, em deliberações tomadas entre os dias 5 e 19 de agosto, resolveu arquivar as onze denúncias e representações contra o senador José Sarney. De fato e de direito, como dissera o professor, "nenhum senador foi punido". Nem Sarney nem ninguém.

\section{A sociedade parece não ter clareza da gravidade da agressão sofrida pelo jornal}

A censura, como seria de esperar, despertou reações vigorosas. De pessoas físicas e jurídicas. A Associação Mundial de Jornais (WAN), Fórum Mundial de Editores (WEF), a Federação Nacional dos Jornalistas (Fenaj) e outras entidades 
se levantaram contra a violência. Todas as reações, entretanto, ficam abaixo da gravidade da agressão cometida por um alto representante do Poder Judiciário contra o direito à informação de que todo cidadão é titular.

A censura judicial, tal como vem se disseminando no país, não deveria ter lugar na democracia. Tristemente, temos verificado que, de uns tempos para cá, tem havido uma preocupante avalanche de medidas judiciais que impedem os mais diversos jornais de tocar em assuntos ou nomes de pessoas. Numa das mais pitorescas, o humorista José Simão, da Folha de S.Paulo, foi proibido por várias semanas de escrever o nome de uma atriz de novela.

Num artigo recente, Judith Brito (2009), presidente da ANJ e diretorasuperintendente da Empresa Folha da Manhã S. A., sintetizou de modo bastante didático o que vem se passando. Como ela soube demonstrar com clareza, não se trata de protestar contra o direito do cidadão de recorrer ao Judiciário com o objetivo de proteger sua intimidade ou de reparar danos sofridos. O que deve ser repudiado, com vigor, é o instituto da censura prévia, aquela que impede que um assunto chegue ao conhecimento do público. Vejamos algumas passagens do artigo:

Diz o artigo 220 da Constituição que "a manifestação do pensamento, a criação, a expressão e a informação, sob qualquer forma, processo ou veículo, não sofrerão qualquer restrição". Esse é um princípio clássico do Estado de Direito e das verdadeiras democracias. Ou seja: todo mundo tem direito a dizer o que quiser e não cabe a ninguém definir previamente o que pode ser dito.

Outra coisa completamente diferente é o fato de que todo mundo também está sujeito a punições e aos rigores da lei caso use esse direito supremo da liberdade de expressão para caluniar ou mentir. Para esses casos, cabe recorrer à Justiça, que poderá aplicar a legislação de danos morais e/ou o direito de resposta. A ampla e irrestrita liberdade de expressão, portanto, não é um direito absoluto, mas precede os demais.

$[\ldots]$

Tomemos como exemplo o recente caso da decisão de um desembargador do Distrito Federal de proibir o jornal $O$ Estado de S. Paulo e toda a mídia brasileira de divulgar fatos relacionados à investigação da Polícia Federal relativa ao empresário Fernando Sarney. Alguém tem dúvida de que isso é de interesse público?

Mais do que isso, não cabe a ninguém decidir previamente se o direito individual de quem quer que seja está sendo ferido pela divulgação de informação. Esse julgamento só pode se dar posteriormente à divulgação.

Assim como a eventual punição.

[...]

O impedimento da divulgação de informações é censura pura e simples.

Essas sentenças liminares acabam sendo revogadas por instâncias superiores do Judiciário. Mas, por menor que tenha sido o período de tempo de exercício da censura, o mal já foi feito. A sociedade foi tolhida no seu direito de ser livremente informada. 
Judith Brito lembra ainda que a ANJ denunciou 31 casos de violação à liberdade de imprensa ocorridos nos últimos 12 meses. Desses, 16 foram de decisões da Justiça de censura prévia. Ela tem razão ao dizer que esse tipo de medida é inaceitável. Mas, em função de lacunas da formação democrática, própria da nossa cultura política, seus argumentos não são compreendidos com a devida clareza pelo senso comum e, de modo especial, pela média dos políticos brasileiros. De que modo isso acontece, qual é de fato a visão comum, hoje, entre os parlamentares e os políticos sobre esses temas, é algo que escapa ao alcance deste pequeno artigo - algo que deveria ser objeto de outro estudo, que envolvesse uma pesquisa direta com agentes políticos. Por ora, fixemo-nos em linhas gerais sobre as dificuldades culturais que emperram a compreensão devida das razões pelas quais não é aceitável que um poder de Estado obstrua o acesso do cidadão à informação que ele tem direito de receber.

\section{Três crenças enganosas que justificam cerceamentos da imprensa}

\section{O que corre em sigilo de Justiça não pode ser noticiado.}

A primeira crença joga sobre os repórteres uma responsabilidade que não é deles. Jamais poderia ser deles. Se algo tramita em segredo no Judiciário, o Judiciário que cuide bem de seu segredo. Até aí, perfeito. Se, por algum deslize, o que era confidencial "vaza", como se diz no jargão político, se é de interesse público e chega às mãos de um jornalista, ele tem o dever de, em princípio, publicar a informação. Seu pacto de lealdade é com o cidadão, não com as autoridades preocupadas em guardar seus segredos. Uma vez na mão de um jornalista, a informação ingressa em outro campo: o campo público. Sejam segredos de Justiça, segredos industriais, e mesmo os segredos de Estado - a imprensa olha para eles como notícia.

Pode soar um tanto inflexível e pincipista dizer isso com tanta assertividade, mas é necessário. Uma vez, o The New York Times traiu esse compromisso de noticiar o que é de interesse público. Seus jornalistas ruminaram por muitos anos o fel do arrependimento. Em 1961, o Times tinha pronta uma reportagem sobre a preparação da invasão da Baía dos Porcos, em Cuba. Forças integradas por exilados cubanos vinham recebendo treinamento da CIA e logo dariam início à operação. Por influência do presidente Kennedy, que teria alegado razões de segurança nacional, os editores do mais influente diário do mundo preferiram atenuar a reportagem, que saiu sem nada dizer sobre a invasão da Baía dos Porcos, que era iminente (Lambeth, 1992, p.31, 120). O jornalista Gay Talese (2000, p.17) conta que, mais tarde, após o fracasso da investida contra a ilha de Fidel, "até o presidente Kennedy reconheceu que o Times talvez tivesse exagerado na sua preocupação de defender os interesses americanos; se tivesse publicado tudo o que sabia sobre a aventura cubana, sugeriu Kennedy, a invasão poderia ter sido cancelada e o fiasco sangrento, evitado".

Jornalistas não são responsáveis por acobertar segredos dos poderes da República. Ao contrário: por mais chocante que isso possa parecer aos ouvidos 
de agentes políticos brasileiros, jornalistas são responsáveis precisamente por descobrir e publicar esses segredos. É simplesmente o oposto. Se não é para publicar o que o poder gostaria de esconder, para que serve o jornalismo? De que adianta a imprensa se não para noticiar segredos? Ela é capaz de vigiar o poder se for solidária com ele na tarefa de silenciar sobre os segredos?

Sigamos adiante. Se um segredo como o da Baía dos Porcos deveria ter sido revelado até mesmo na opinião de Kennedy, por que o sigilo de Justiça deve ser considerado assunto proibido? Com que legitimidade uma medida judicial pode barrar o direito à informação?

É nesse sentido que a decisão do desembargador do TJ-DF é censura prévia. Não há outro nome para a ordem que ele deu. Sendo censura, é inconstitucional. E, sendo inconstitucional, essa medida não deveria mais ser tolerada no Brasil. Sigilos de Justiça devem ser mantidos em sigilo - isso é uma verdade inquestionável, uma tautologia ululante. Agora, se descobertos, os sigilos (também de Justiça) devem ser publicados, quando de interesse público.

\section{Em casos de risco, a Justiça deve impedir previamente que os jornais devassem a intimidade familiar.}

Temos aqui outro mito perigoso. Em princípio, são muitos os que tendem a concordar com ele. "O que você escolheria?", eles perguntam. "Ter protegida a sua privacidade ou deixar que qualquer jornalista, a qualquer momento, divulgasse qualquer coisa que bem entendesse?”

Posta dessa forma, a interrogação não nos deixa escolha. Temos de proteger a nossa privacidade, com todas as medidas preventivas possíveis. Acontece que a liberdade de expressão significa exatamente isso: os cidadãos, todos eles, não apenas os jornalistas, têm o direito - e devem ter os meios - de declarar, informar, manifestar qualquer coisa que bem entendam, a qualquer momento, sobre o que quer que seja. É claro que, depois, terão de responder perante a Justiça sobre os excessos que porventura vierem a cometer. Mas posteriormente, não antes de publicar. Isso é liberdade de expressão - e, de modo especializado, isso é liberdade de imprensa. Ou uma democracia garante essa liberdade ou ela não é democracia.

No mais, estamos todos expostos a esses inconvenientes, o tempo todo. Como acreditamos e prezamos a liberdade de imprensa, estamos expostos aos erros da imprensa, às atribulações do sensacionalismo, às invasões de privacidade injustificadas. Mas liberdade é liberdade. Ou convivemos os riscos que ela acarreta, ou não a temos.

No momento da tomada de decisões editoriais sobre o que vai e o que não vai ao ar, cabe às redações, e não ao Judiciário, avaliar se uma notícia merece ou não merece ser publicada. Elas, as redações, responderão por isso depois, mas, na hora da decisão editorial, devem consultar apenas suas próprias referências autônomas - os cânones do jornalismo, a ética da profissão, os direitos do público, o interesse do leitor. Não precisam nem devem levar em conta os palpites 
de autoridades externas, sejam elas do Poder Judiciário, da Presidência da República ou do Vaticano.

Diante de uma informação que aparenta estar circunscrita ao âmbito da intimidade familiar, as redações devem avaliar se ela é de interesse público. Se for, terá de ser publicada, mesmo que essa veiculação arranhe, em algum grau, aspectos da vida privada de alguém. Muitas vezes, ou, melhor, quase sempre, os crimes contra o patrimônio público são urdidos, tramados, planejados e executados na esfera íntima - daí a dificuldade extrema desse tipo de decisão editorial. Jornalistas convivem com isso quase que diariamente - e a decisão é sempre difícil.

Em suma, o Judiciário não apenas não deve impedir preventivamente nada de ser publicado, como, à luz da Constituição, o Judiciário não pode fazê-lo. Tanto é assim que todas essas decisões excêntricas terminam por ser derrubadas nas instâncias superiores, onde, para sorte dos brasileiros, há um pouco mais de clareza sobre o espírito da democracia.

\section{A imprensa é um partido de oposição.}

Foi José Sarney quem disse: "A mídia passou a ser uma inimiga do Congresso, uma inimiga das instituições representativas". A declaração, noticiada no Estadão de 16 de setembro de 2009, dialoga com uma estreiteza que ganhou muita solidez em certas hostes da esquerda - não em todas as variantes de esquerda, mas em muitas delas. E também faz escola em círculos de golpistas de direita. Todo o tempo. No dia 28 de setembro de 2009, por exemplo, os militares que destituíram o presidente Manuel Zelaya, em Honduras, fecharam emissoras que não batiam palmas para o governo golpista. ${ }^{8}$ Nenhum poder gosta da imprensa, mas alguns passam das medidas.

Mas, na América Latina de nossos dias, essa construção ideológica de que "a mídia é inimiga das instituições representativas" ganhou colorações mais intensas à esquerda. É bom lembrar que o orador José Sarney é tão de esquerda quanto Paulo Maluf, mas o que ele proclamou parece uma fala raivosa esquerdista - e não esclarecida. É aí que se acalentam utopias autoritárias de tutelar, direcionar, encabrestar os canais de expressão da sociedade. Os adeptos dessas utopias não enxergam que, ao ferirem a autonomia de um veículo, não importa de que filiação doutrinária, estão na verdade sangrando toda a instituição da imprensa. Estão pondo tudo a perder. A garantia da liberdade existe não para dar projeção àqueles que concordam com quem governa - ou conosco. A liberdade existe apenas para assegurar a voz e a influência dos que se opõem. Defender a liberdade dos que dizem sim é algo que até Hitler ou Mao fariam, sem titubear. O difícil - mas o que é vital - é defender a liberdade dos que nos combatem. Principalmente quando os que nos combatem exercem liderança legítima nos espaços públicos.

Tudo bem, são ideias óbvias. Mas essas ideias, por mais óbvias, não foram assimiladas de verdade. Ainda hoje, alguns acalentam o delírio de se valer do poder estatal para intimidar os dissidentes. Para se desculpar em seus espasmos 
que flertam com a tirania, vêm com esse argumento de que "a mídia é inimiga das instituições representativas".

Ora, o risco de que os meios de comunicação se cristalizem como um superpoder político espreitando e ameaçando o próprio Estado é, desde muito tempo, um risco real. O ingresso de comunicadores na cena política está aí para atestar o modo como a comunicação social abre portas para interesses privados na esfera pública. Os exemplos são inumeráveis: eles se estendem desde que o magnata William Randolph Hearst (1863-1951), o mesmo que inspirou o filme Cidadão Kane de Orson Welles (1941), tentou se eleger, primeiro governador de Nova York e, depois, duas vezes prefeito da cidade de mesmo nome ao longo da primeira década do século XX. Hearst fracassou, mas outros que o seguiram tiveram êxito. E nem eram tão inteligentes, tão preparados. $\mathrm{O}$ ator Ronald Reagan e o quase ator Arnold Schwarzenegger saíram do cinema hollywoodiano entraram no Partido Republicano, através do qual puderam exercer cargos públicos de alguma projeção nos Estados Unidos.

Os meios de comunicação servem de trampolim para muitas carreiras políticas. Servem para coisa pior. Todo mundo vem observando isso, pelo menos desde que Tocqueville se impressiona com o poder das massas na América do século XIX, ou desde Weber (2006, p.80), que via na figura do jornalista o novo demagogo. Também Habermas (1984, p.218), em seus primeiros escritos, encontrou formulações que se tornariam clássicas sobre o tema:

A imprensa, que até então fora instituição de pessoas privadas enquanto público, torna-se instituição de determinados membros do público enquanto pessoas privadas - ou seja, pórtico de entrada de privilegiados interesses privados na esfera pública.

Acontece que os desequilíbrios causados pelo excesso de poder concentrado nos meios de comunicação podem ter antídotos democráticos. Quando os antídotos enveredam pelo caudilhismo, quem sai ganhando não é a cura, mas a doença. E soluções democráticas existem. Pense-se, por exemplo, na legislação antitruste adotada pelos Estados Unidos há 70 anos para disciplinar o mercado da comunicação social, com ênfase na radiodifusão. Foi para combater os monopólios e os oligopólios - ou seja, para combater a concentração de poder econômico e político - que os congressistas dos Estados Unidos, ainda em março de 1934, fundaram a Federal Communications Commission (FCC). A agência reguladora americana tem o objetivo declarado de assegurar a pluralidade de vozes e a concorrência saudável entre as diversas empresas do setor de comunicações. É por isso, para atender ao interesse público, que a FCC impõe limites ao oligopólio e ao monopólio. Se um só grupo açambarca o controle das principais estações de rádio e TV numa determinada região, ele açambarca, também, o poder informal de direcionar o debate público segundo seus interesses privados. ${ }^{9}$

No Brasil, ainda não temos uma legislação democrática para o setor. Temos, nesse campo, um dos nossos déficits políticos mais sérios. Não obstante, ao 
Brasil não faltam evidências de que as distorções informativas provocadas pela concentração de poder nos meios de comunicação podem resultar em grandes prejuízos históricos. Uma dessas evidências, talvez a mais traumática, nós a tivemos no primeiro semestre de 1984. Naquele período, milhões de pessoas adensaram comícios na campanha pelas eleições diretas para presidente da República. Com exceções pontuais, as redes de TV, lideradas pela Rede Globo, demoraram exageradamente a registrar jornalisticamente as manifestações. A bem da verdade, boicotaram a campanha. Desse modo, acabaram por ajudar a ditadura a derrotar no Congresso a emenda que restabelecia as diretas, que só viriam em 1989.

Nesse exemplo brasileiro, porém, o da campanha das Diretas Já em 1984, o superpoder dos meios de comunicação não engendrou uma agressão contra as instituições representativas. O que ocorreu foi um pouco diferente disso, mas o sentido foi o mesmo: as emissoras, com as exceções que precisam ser aqui consideradas, se alinharam ao poder estatal autoritário, cujas instituições não eram representativas, para golpear a sociedade que pretendia construir instituições democráticas. Outras vezes, porém, o chamado "poder midiático" dirige seus torpedos diretamente contra as instituições representativas. Isso de fato pode acontecer.

Uma demonstração célebre dessa hipótese teve sede na Venezuela, em 2002, quando, agindo de modo articulado, emissoras de televisão lideraram uma tentativa de golpe contra Hugo Chávez, presidente legitimamente eleito. A Venezuela vivia, então, um período de estabilidade democrática. O golpe das estações de TV terminou derrotado em 72 horas. ${ }^{10}$ Chávez retornou ao governo, vitorioso. Depois, no entanto, o próprio Hugo Chávez, que permanece no poder até hoje, passou a perseguir e fechar televisões que não são simpáticas ao seu governo, cerceando a liberdade de imprensa e tentando fortalecer uma comunicação estatal não democrática. Outra vez, a tensão estrutural entre o poder político e os meios de comunicação volta a se manifestar com tintas preocupantes.

Enfim, o que importa nesta conclusão é deixar bem registrado que o risco de que os conglomerados da comunicação se insurjam contra a sociedade e contra o Estado de Direito não é desconhecido. Trata-se de um risco real. Mas, nem de longe, esse risco paira hoje no horizonte da democracia brasileira. Por isso, na voz do presidente do Senado, o discurso de "mídia inimiga" soa como dadaísmo político, além de conter um problema semântico. Sarney disse "mídia" para designar a imprensa, o que, aliás, mais que um problema semântico, redunda numa irresponsabilidade política. ${ }^{11}$

A instituição da imprensa só existe quando a liberdade de expressão tem vigência plena. Seu corpo está nos jornais e nas revistas, nas emissoras de rádio e televisão, nos blogs e no debate público; seu corpo está, enfim, nesse conjunto plural dos meios. Mas sua dimensão maior, não corpórea, é a liberdade. Trata-se de uma dimensão não corpórea, indispensável à vigência dos direitos democráticos e ao próprio funcionamento da democracia. Por isso, a imprensa como ins- 
tituição é maior - e mais preciosa - do que o mero somatório dos veículos. Por isso, quando o poder agride um único veículo, está fazendo sangrar a instituição da imprensa como um todo. Está enfraquecendo todo o sistema democrático. Está atentando contra os direitos fundamentais de cada cidadão.

Alguns dizem que "a mídia é um partido de oposição". Além de bobagem, temos aí uma típica retórica demagógica. É claro que se podem, por meio de uma verificação banal, avaliar as posições médias dos editoriais dos principais diários brasileiros sobre questões como privatização, política externa ou aborto. Pode-se mesmo constatar que haja concordância em alguns desses pontos entre os maiores jornais. Daí a dizer que "a imprensa no Brasil tem essa posição" ou que "a mídia faz oposição ao governo" vai uma enorme distância - vai, às vezes, também, uma pitada de má intenção: a de procurar demonstrar que a instituição da imprensa deve ser enquadrada porque alguns veículos, segundo esse tipo de análise, agiriam como defensores de causas partidárias.

Trata-se de um sofisma, quando não de uma calúnia. Por vários motivos, entre eles, um motivo elementar: a imprensa, como instituição, inclui todos os jornais, os grandes e os pequenos, os influentes e os desprezíveis, assim como inclui também cada $b \log$, cada estação de TV ou de rádio. Usar esse tipo de categorias totalizantes, nesse caso, categorias como "a mídia" ou "a grande mídia", traz sempre uma ameaça velada à liberdade. É preciso ir com calma.

Há mais ainda. Ao publicar reportagens que apontam suspeitas de irregularidades no poder público, nenhum jornal está se insurgindo contra as instituições. Ora, o que se dá é justo o oposto: ao publicar uma reportagem responsável, bem apurada, bem checada, dando conta de irregularidades na administração do Estado, um jornal está, isto sim, defendendo a saúde e a integridade das instituições. Por isso, no que vivemos ao longo dos sucessivos escândalos do Senado, não é lógico nem é de boa-fé afirmar que a imprensa seria inimiga das instituições representativas. Ao longo desse triste período, ela foi a melhor - e às vezes única - amiga das instituições representativas. Com destaque para a conduta do jornal O Estado de S. Paulo, que acabou, no fim, premiado por uma censura que já se estende por mais de dois meses ininterruptos. É uma ironia mais que perversa. Nenhuma das reportagens do Estadão sobre os desmandos no Senado faltou com a verdade. Nenhuma de suas notícias foi mentirosa. E o que é que o jornal ganhou ao final de sua brilhante trajetória? A mordaça. É como se, por ter sido "inimigo" das instituições, levasse o castigo merecido. Nada mais justo, diria um certo senador. Esse mesmo senador talvez dissesse que a culpa por tudo isso é do Estadão. A culpa, como dizem os homens do poder, é sempre da imprensa.

Notas

1 O diálogo está transcrito em Schubsky et al. (2007, p.219-26).

2 Desenvolvi parte dessa análise em Bucci (2009a). 
3 Ver no Globo Online de 12 de março de 2009, ou na Folha de S.Paulo do dia 13 de março, na matéria "Sarney usa polícia do Senado para vigiar casa".

4 "A reação é tão grande hoje contra o parlamento que talvez fosse a hora de fazer um plebiscito para saber se o povo quer ou não que o parlamento continue aberto", declarou o pedetista.

5 Comentei as declarações em artigo escrito para o site Observatório da Imprensa, sob o título de "Pobres deles, tão perseguidos", postado no dia 14 de abril de 2009 (disponível em: http://www.observatoriodaimprensa.com.br/artigos.asp?cod=533JDB001).

6 A retrospectiva que se segue é a transcrição, com adaptações mínimas, do que foi publicado pelo Estadão em sua edição de 29 de setembro de 2009.

7 Também estive presente a esse debate. Seus trechos mais importantes foram publicados pelo Estado na edição de 8 de agosto de 2009, sob o título de "Nenhum senador foi punido. Só o jornal”.

8 Conforme noticiou a $\mathrm{BBC}$, "forças militares hondurenhas entraram nesta segundafeira (28/09/09) nas instalações da Rádio Globo e da emissora de televisão Canal 36, na capital Tegucigalpa, e obrigaram as duas empresas a encerrarem suas transmissões" (disponível em: http://www.bbc.co.uk/portuguese/noticias/2009/09/090928_ honduras_emissoras_cq.shtml).

9 Tratei disso no artigo "Os inimigos" (Bucci, 2009b).

10 Ver, sobre o "golpe mediático", The revolution will not be televised, documentário de Kim Bartley e Donnacha O'Briain, Irlanda, 2003. Os diretores são dois documentaristas independentes que estavam no palácio do governo em Caracas, em 11 abril de 2002, e acabaram filmando todo o golpe, até a volta de Hugo Chávez. O filme está disponível em http://video.google.es/videoplay?docid=5832390545689805144\#d ocid=-3378761249364089950.

11 Conforme observei em artigo para o Estadão, já citado, há um problema semântico na frase de Sarney. O que é que ele quer designar com esse novíssimo substantivo, "mídia"? Sarney parece ter usado "mídia" como sinônimo de imprensa. "Mídia" e “imprensa” são objetos distintos. "A mídia”, um aportuguesamento da pronúncia inglesa da palavra latina media (meios), plural de medium (meio), é um vocábulo que não deveria existir em português. Deveríamos falar simplesmente "meios". Mas, como a língua só evolui no erro, a palavra “mídia” entrou no dicionário e, dentro dele, engloba sentidos que cobrem todos os meios e todos os seus conteúdos, dos outdoors às telas de cinema, dos programas de auditório aos caminhões com alto-falante que anunciam pamonhas, dos jornais diários às propagandas de automóveis coladas nas poltronas de avião. Aí está o problema semântico: dizer que essa imensidão de mensagens e veículos tenha se voltado contra o Congresso Nacional é apenas uma sandice. Não faz sentido nenhum.

Referências bibliográficas

BRITO, J. Censura prévia é inadmissível. Folha de S.Paulo, São Paulo, 27 ago. 2009. p.A3.

BUCCI, E. A imprensa e a fala do Poder. O Estado de S. Paulo, São Paulo, 12 fev. 2009a. p.A2. 
BUCCI, E. Os inimigos. O Estado de S. Paulo, São Paulo, 24 set. de 2009b. p.A2.

HABERMAS, J. Mudança estrutural da esfera pública. Rio de Janeiro: Tempo Brasileiro, 1984.

LAMBETH, E. B. Committed journalism - An ethic for the Profession. 2.ed. s. 1.: Indianna University Press. 1992.

MAMOU, Y. A culpa é da imprensa. São Paulo: Marco Zero, 1992.

PULITZER, J. The School of Journalism. Seattle: Inkling Books, 2006.

SCHUBSKY, C. et al. (Org.) Estado de Direito Já! - Os trinta anos da Carta aos Brasileiros. São Paulo: Lettera.doc, 2007.

TALESE, G. O Reino e o poder. São Paulo: Cia. das Letras, 2000.

WEBER, M. Ciência e politica, duas vocações. São Paulo: Cultrix, 2006.

Eugênio Bucci é professor doutor da Escola de Comunicações e Artes da USP e pesquisador do Instituto de Estudos Avançados da USP. Autor, entre outros livros, de Sobre ética e imprensa (Cia. das Letras, 2000), Em Brasilia, 19 horas (Record, 2008) e $A$ imprensa e o dever da liberdade (Contexto, 2009). Escreve quinzenalmente para $O$ Estado de S. Paulo e para o site Observatório da Imprensa.

@ - eugeniobucci@uol.com.br

Texto recebido em 5.10.2009 e aceito em 9.10.2009. 